\title{
A 548-YEAR TREE-RING CHRONOLOGY OF OAK (QUERCUS SPP.) FOR SOUTHEAST SLOVENIA AND ITS SIGNIFICANCE AS A DATING TOOL AND CLIMATE ARCHIVE
}

\author{
KATARINA ČUFAR ${ }^{1 *}$, MARTÍN DE LUIS ${ }^{2}$, MARTIN ZUPANČIC ${ }^{1}$, and DIETER ECKSTEIN ${ }^{3}$ \\ ${ }^{1}$ University of Ljubljana, Biotechnical Faculty, Dept. of Wood Science and Technology, Rožna dolina, Cesta VIII/34, \\ SI-1000 Ljubljana, Slovenia \\ ${ }^{2}$ University of Zaragoza, Dept. Geografía y O.T., C/Pedro Cerbuna 12, E-50009 Zaragoza, Spain \\ ${ }^{3}$ University of Hamburg, Dept. of Wood Science, Division Wood Biology, Leuschnerstr. 91, D-21031 Hamburg, Germany
}

\begin{abstract}
Tree-ring series of oak, from both living trees (Quercus petraea and Q. robur) and historic timbers in southeastern Slovenia were assembled into a 548-year regional chronology spanning the period A.D. 1456-2003. It is currently the longest and the most replicated oak chronology in this part of Europe located at the transition between Mediterranean, Alpine and continental climatic influence. The chronology correlated significantly with regional and local chronologies up to $700 \mathrm{~km}$ away in Austria, Hungary, Serbia, Czech Republic and southern Germany. It also showed good "heteroconnection", i.e. agreement with chronologies of beech (Fagus sylvatica), ash (Fraxinus excelsior) and silver fir (Abies $a l b a)$ in Slovenia. A preliminary dendroclimatic analysis shows that precipitation and temperature in June accounted for a high amount of variance $\left(r^{2}=0.51\right)$ in the tree-ring widths. The chronology thus contains considerable potential as a climate archive. We also present its use as a tool for the dating of wooden objects of the cultural heritage. Moreover, the chronology can be a point of reference for building tree-ring chronologies in neighboring regions.
\end{abstract}

Keywords: Dendrochronology, teleconnection, heteroconnection, dendroclimatology, paleoenvironment, historic buildings.

\section{INTRODUCTION}

Long tree-ring chronologies are gaining increasing interest as precise reference standards for dating historical and prehistorical wood (e.g. Baillie 1995) and as useful records of paleoenvironmental information (e.g. Cook and Kairiukstis 1990). During recent decades, dendrochronological techniques, among others, have been applied to reconstruct past climate, forest disturbances and past forest management practices, fire history in various woodlands, past forest insect infestations, geomorphological processes, as well as past earthquakes (e.g. Schweingruber 1988) and, last but not least, for dating pre-historic and historic human activities (e.g. Dean 1996).

\footnotetext{
* Corresponding author: katarina.cufar@bf.uni-lj.si; Fax +386-1-423-50-35; Telephone +386-1-423-11-61
}

In Central and Western Europe, oak (Quercus spp.) is the most important tree and timber in dendrochronology. The genus Quercus is here mainly represented by pedunculate (Quercus robur L.) and sessile oak (Quercus petraea Liebl.), which cannot be fully differentiated in terms of their wood anatomy. Long oak chronologies are composed of living and sub-fossil trees, as well as of wood from historical and archaeological remains. Some of them cover several millennia and have been successfully used to date wood from the distant past and to derive paleo-environmental or paleo-climatic information (e.g. Eckstein and Wrobel 1982; Becker and Schmidt 1990; Wazny and Eckstein 1991; Lavier 2000; Baillie and Brown 2002; Leuschner et al. 2002; Billamboz 2003; Friedrich et al. 2004). Even under sub-optimal dendrochronological conditions, such as in Flanders, Belgium, it has been shown that dendro- 
chronological dating is possible and can provide valuable information on medieval forest management practices (Haneca et al. 2006).

It has been shown that well-replicated treering chronologies of oak are very similar to each other throughout much of Central and Western Europe (teleconnection), indicating that oak growth is affected by a supra-regional common factor (Baillie 1995; Kelly et al. 2002). The construction of long regional oak chronologies in the countries south, southeast and east of the Alps has not been equally successful, however. Several chronologies have been established, for example in Italy and Hungary (Martinelli 1990; Nola 1991; Martinelli et al. 1992, 1994; Grynaeus 1996, 2000), but they are of local significance and based on living trees only. Likewise in Slovenia, which is influenced by Alpine, Mediterranean and continental climate regimes and characterized by a wide phytogeographic variability, all attempts to construct a long regional oak chronology thus far have been discouraging for various reasons. The local tree-ring chronologies of various sites, for example, differ from each other to a large extent, particularly in the case of fast-growing oak trees on lowland sites (Čufar and Levanič 1999a,b), where tree growth is often affected by micro-site influences like ground water level (Levanič 1993; Čater 2003; Čater and Levanič 2004; Čater and Batič 2006). Therefore, it has neither been possible to extend them with tree-ring series of wood from the past nor to teleconnect them with chronologies from north of the Alps.

Nevertheless, a long reference chronology is indispensable for Slovenia and the neighboring regions in order to date wood representing the cultural heritage of the region and to obtain more information on past climate fluctuations and the paleo-environment. The objectives of this study, therefore, were (1) to construct an oak chronology for southeast Slovenia combining tree-ring series from living trees and from historic timbers, (2) to use the potential of this oak chronology as a dating tool, including teleconnection with oak chronologies in distant regions and correlation with other tree species ("heteroconnection") in the same region, such as beech (Fagus sylvatica L.), ash (Fraxinus excelsior L.) and silver fir (Abies alba Mill.), (3) to explore its potential as a climatic proxy, including the detection of climatic factors affecting tree growth, and their stability in time, and (4) to present its potential for dating wood from historic buildings and reconstruct past human activities.

\section{MATERIAL AND METHODS}

\section{Study Area and Wood for Tree-Ring Research}

The sampling area is located east and southeast of Ljubljana, Slovenia (Figure 1). The climate is temperate humid and characterized by the transition from a sub-Mediterranean to a subcontinental precipitation regime (Ogrin 1996). Phytogeographically, the region belongs to the southeastern Alpine division of the Illyrian province, with prevailing mixed deciduous forests. The predominant tree species are beech, sessile oak, pedunculate oak, sweet chestnut (Castanea sativa Mill.), hornbeam (Carpinus betulus L.) and Norway spruce (Picea abies Karst.). The natural oak sites have been mostly deforested for the benefit of agricultural production.

The wood used to construct the regional treering chronology originated from old grown oak trees in the forest districts Celje (CE) (10 trees), Novo mesto (NM) (12) and Ljubljana (LJ) (29). It was collected during regular harvesting in 2003 and 2004 or from the archive of the Department of Wood Science and Technology, Ljubljana as disks from felled trees or cores from living trees of mainly sessile oak.

The timbers for extension of the regional treering chronology originated from historic rural buildings, such as farm houses, barns and hay lofts, and from one church tower (Figure 1). The building timbers were very likely provided from nearby forests. The samples were collected by coring or sawing. The number of samples varied in accordance with the availability and condition of the timbers. We could not in general differentiate between sessile and pedunculate oak with certainty.

\section{Dendrochronological Analysis}

The samples were polished and the tree-ring widths measured to the nearest $0.01 \mathrm{~mm}$. The 

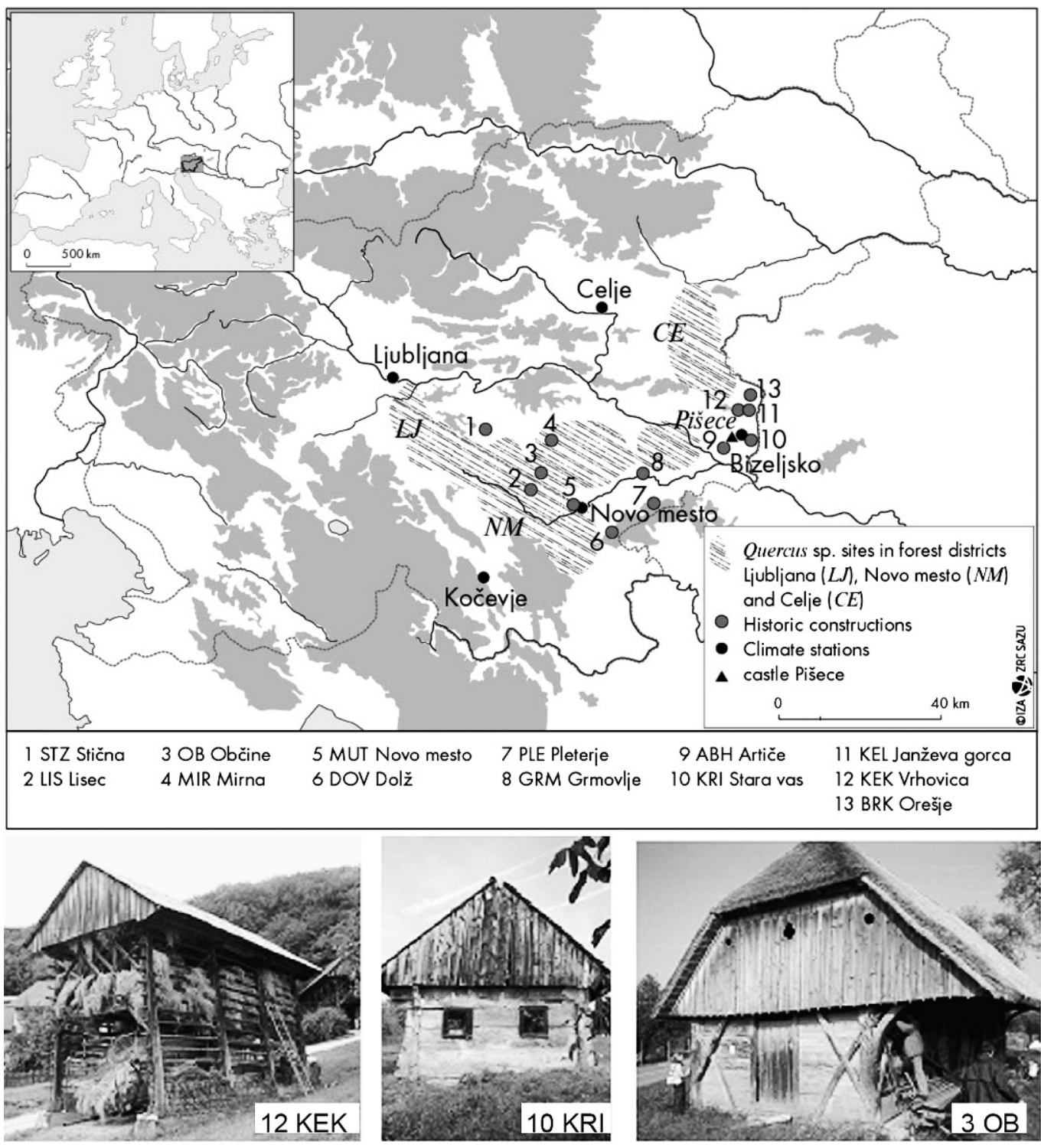

Figure 1. Map of Slovenia with the locations of the forest sites, historic buildings, climate stations (Ljubljana $46^{\circ} 04^{\prime} \mathrm{N}, 14^{\circ} 29^{\prime} \mathrm{E}$, $299 \mathrm{~m}$ a.s.l.; Celje $46^{\circ} 15^{\prime} \mathrm{N}, 15^{\circ} 15^{\prime} \mathrm{E}, 240 \mathrm{~m}$ a.s.l.; Novo mesto $45^{\circ} 48^{\prime} \mathrm{N}, 15^{\circ} 11^{\prime} \mathrm{E}, 220 \mathrm{~m}$ a.s.l.; Bizeljsko $\left(46^{\circ} 01^{\prime} \mathrm{N}, 15^{\circ} 42^{\prime} \mathrm{E}, 179 \mathrm{~m}\right.$ a.s.l.; Kočevje $45^{\circ} 39^{\prime} \mathrm{N}, 14^{\circ} 51^{\prime} \mathrm{E}, 467 \mathrm{~m}$ a.s.l.) and castle of Pišece. Inset shows the location of Slovenia within Europe. Below are examples of typical rural buildings in the study region: hay loft (12 KEK), wooden house (10 KRI) and barn (3 OB)

TSAP/X program (Frank Rinn, Heidelberg, Germany) was used for data acquisition. The tree-ring series were visually and statistically crossdated and compared with each other by calculating the tvalue after Baillie and Pilcher (1973) using TSAP/ $\mathrm{X}$ and TSAP-Win. We then established 16 nondetrended, raw-data chronologies (three chronol- ogies of living trees and 13 chronologies of buildings or building groups) and checked their intercorrelation (Figure 2, Table 1).

Because the three chronologies of living trees were highly similar to each other ( $\mathrm{t}$-values between 6.4 and 7.1), we decided to use all 16 chronologies to assemble one regional chronology for southeast 


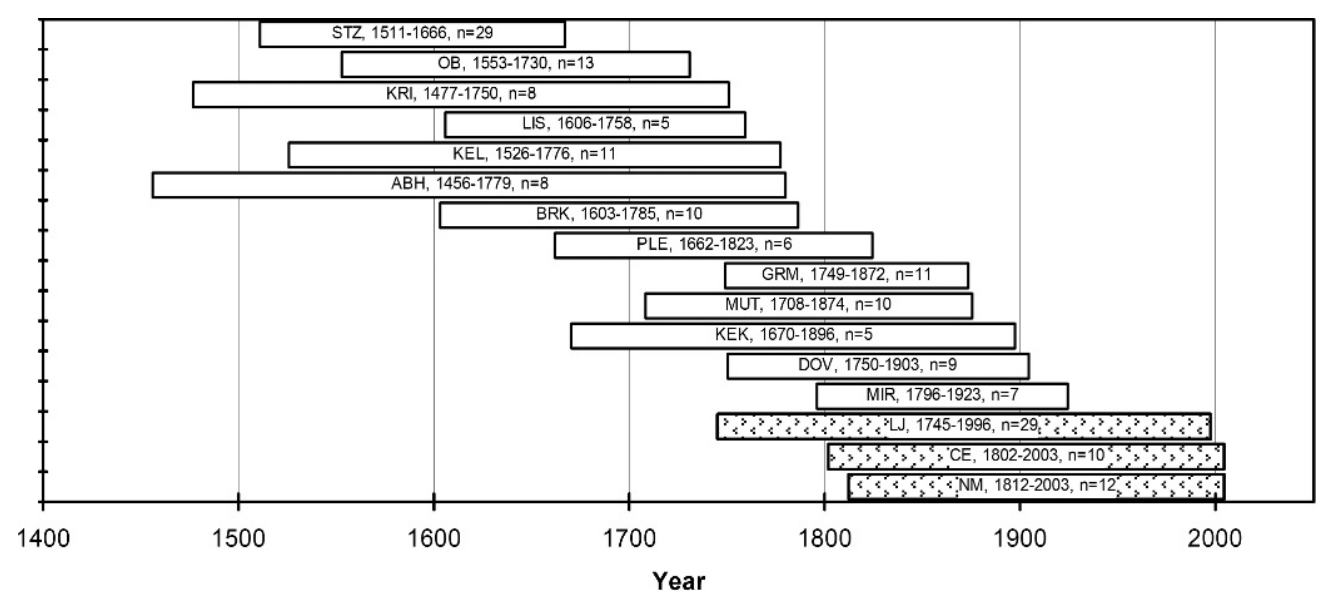

Figure 2. Time span, number of samples (n) and overlapping of the chronologies from living trees (hatched bars) and buildings (white bars); compare Figure 1 and Table 1.

Slovenia. We made two versions of this regional chronology, a non-detrended, raw-data and a detrended, residual chronology.

\section{Raw-data Chronology, Teleconnection and Heteroconnection}

The non-detrended, raw-data regional chronology was tested for teleconnection and heteroconnection. To test for teleconnection, we compared the southeast Slovenian chronology with oak chronologies in Austria (Wimmer and Grabner 1998; Grabner, personal communica- tion), Hungary (Grynaeus 2000; Morgos and Schmidt, personal communication), Serbia ( $\check{C} u-$ far and De Luis, unpubl.), Czech Republic (Tegel, personal communication) and south Germany (Becker 1993; Friedrich, personal communication), all provided from the personal sources. To test the heteroconnection, we used one chronology of beech from southeastern Slovenian hills (Di Filippo et al. 2007), one regional chronology of silver fir (Levanič and Čufar 1997; Čufar, unpubl.), and one local chronology of ash (Čufar and Levanič 1999a), all from Slovenia.

Table 1. Crossdating parameters (t-values) of overlapping chronologies. For the location, type, time span and overlapping of the chronology, compare Figures 1 and 2 . The t-value is not given if overlapping is less than 50 years or when $\mathrm{t}<3$.

\begin{tabular}{|c|c|c|c|c|c|c|c|c|c|c|c|c|c|c|c|}
\hline Chronology & STZ & OB & KRI & LIS & KEL & $\mathbf{A B H}$ & BRK & PLE & GRM & MUT & KEK & DOV & MIR & LJ & $\mathrm{CE}$ \\
\hline OB & 8.1 & & & & & & & & & & & & & & \\
\hline KRI & 3.0 & 3.0 & & & & & & & & & & & & & \\
\hline LIS & & 10.6 & & & & & & & & & & & & & \\
\hline KEL & 3.5 & 6.4 & 4.0 & 4.4 & & & & & & & & & & & \\
\hline $\mathbf{A B H}$ & 3.7 & 7.3 & 8.2 & 4.3 & 7.7 & & & & & & & & & & \\
\hline BRK & & 4.4 & & 4.1 & 7.6 & 7.0 & & & & & & & & & \\
\hline \multicolumn{16}{|l|}{ PLE } \\
\hline GRM & & & & & & & & 5.1 & & & & & & & \\
\hline MUT & & & & & & & & 3.2 & 8.6 & & & & & & \\
\hline KEK & & 3.0 & & & 7.5 & 3.5 & 5.1 & 5.4 & 4.8 & 6.1 & & & & & \\
\hline DOV & & & & & & & & & 4.9 & 5.8 & 3.2 & & & & \\
\hline MIR & & & & & & & & & 5.0 & 5.8 & 3.2 & 5.6 & & & \\
\hline LJ & & & & & & & & & & & 3.5 & & & & \\
\hline CE & & & & & & & & & 3.9 & 4.2 & 3.4 & 3.3 & 4.6 & 6.4 & \\
\hline NM & & & & & & & & & 3.0 & & & 4.0 & 5.3 & 6.4 & 7.1 \\
\hline
\end{tabular}




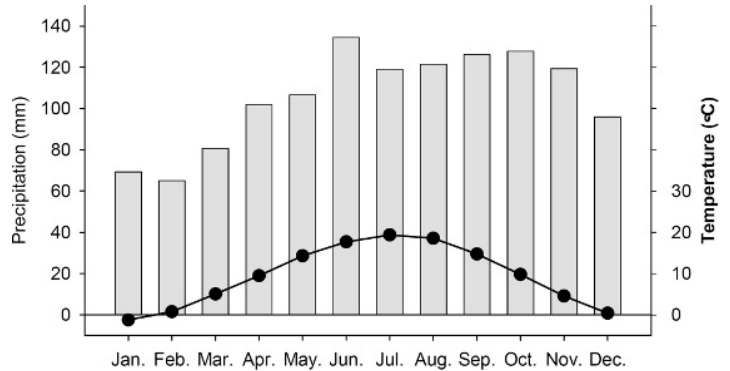

Figure 3. Climatic diagram, mean monthly average temperature (line) and mean monthly sum of precipitation (bars), integrated from the stations Ljubljana, Celje, Novo mesto, Bizeljsko and Kočevje for the period 1899-2003. The mean annual precipitation is $1,268 \mathrm{~mm}$ and the mean annual temperature is $9.5^{\circ} \mathrm{C}$.

\section{Tree-Ring Growth and Climate}

The climatic influence on tree growth was studied using the residual version of the chronology obtained by the program ARSTAN (Holmes 1994), by which the individual raw tree-ring series were standardized in a two-step procedure. First, the long-term trend was removed by fitting a negative exponential function or a regression line to each tree-ring series. Second, a more flexible detrending was made by a cubic smoothing spline with a 50\% frequency response of 60 years to further reduce non-climatic variance. Subsequently, autoregressive modeling of the residuals and biweight robust estimation of the mean were applied (Cook and Peters 1997).

The climatic data were obtained from the meteorological stations Ljubljana, Celje, Novo mesto, Bizeljsko and Kočevje of the Environmental Agency of the Republic of Slovenia within the Ministry of the Environment, Spatial Planning and Energy. The stations are representative for the sampling area (Figure 1). The individual climate records were checked for homogeneity according to Alexandersson (1986). We standardized the individual climate series and then averaged them to obtain a regional climate data set for the period 1899-2003 (Figure 3).

The climate/growth relationships were calculated using the program DendroClim2002 (Biondi and Waikul 2004), whereby the residual version of the tree-ring chronology was the dependent variable and the regressors were the monthly mean temperatures and the monthly sums of precipitation for each biological year from the previous October to the current September. Total variance in tree-ring chronologies accounting by climate was calculated using forward stepwise regression techniques with the same dependent variable and regressors. The stability in time of the climate/growth relationships was checked by moving the correlation and the response function, calculated for a time window of 60-year length, over the time axis from 1900 to 2003 (Biondi 1997). The program DendroClim2002 applies a bootstrap process according to Guiot (1991) to assess the statistical significance of the correlation and response function.

\section{RESULTS}

\section{The Tree-Ring Chronology of Oak for Southeast Slovenia}

The regional oak chronology for southeast Slovenia is 548 years long and covers the period 1456-2003 (Figure 4). It was derived from 183 trees with a total of 18,390 rings. The mean length of the single tree-ring series included is 100 years. The interval of the chronology replicated with 17 or more trees and subsample signal strength (SSS) $>0.85$ extends from 1549 to 2003. The statistics of both the raw-data and residual chronologies are given in Table 2.

\section{Teleconnection and Heteroconnection}

The results of teleconnection of the chronologies are given in Figure 5 (for each area or data source, we listed the best matching chronology). The similarity depends on the length of overlap and on the geographical position, quality, and replication of the chronology. The highest agreement $(t=9.7)$ was obtained with the east Austrian chronology, which is geographically the nearest regional chronology. High and significant agreements were also obtained for the regional chronologies of Hungary, Moravia (Czech Republic) and southern Germany as well as for the local chronologies of Hungary and Srem (Serbia) (Figure 5). 


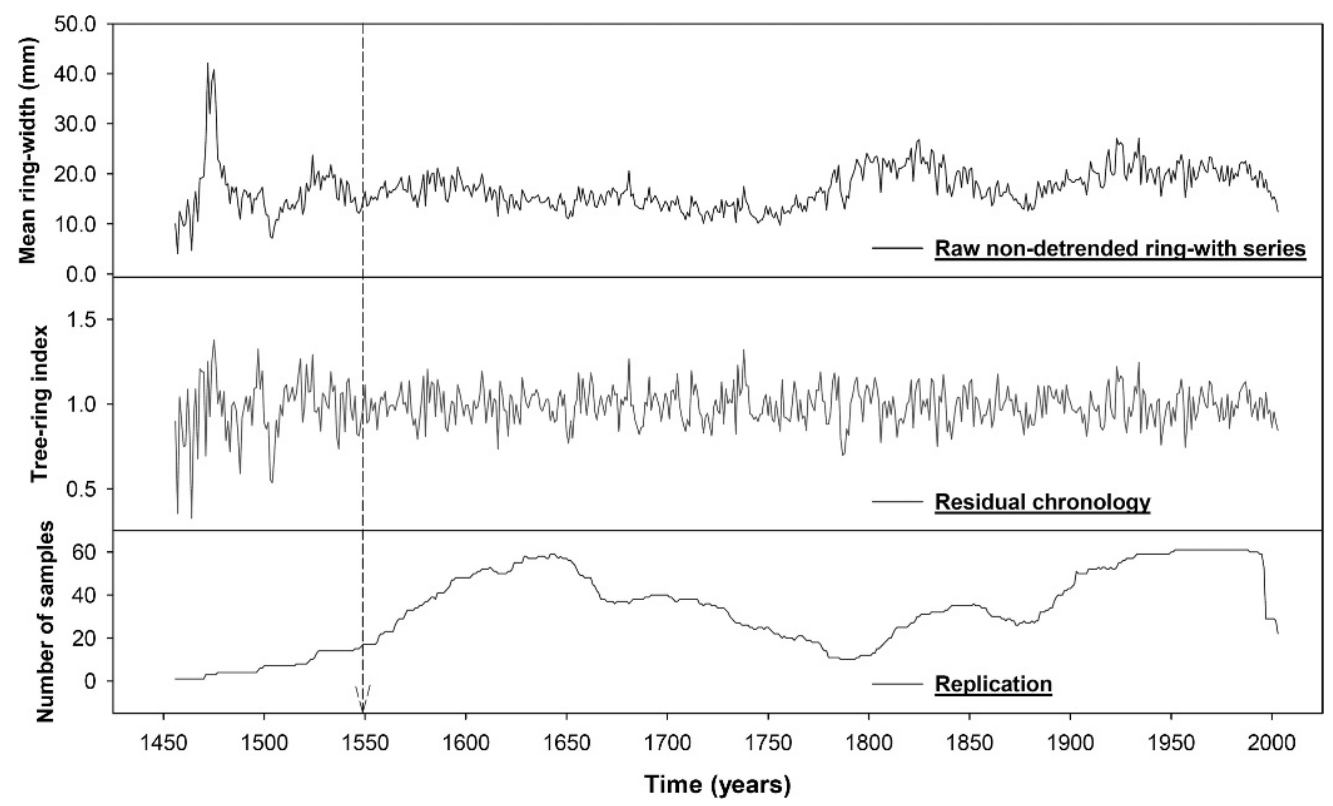

Figure 4. Regional oak tree-ring chronology of southeast Slovenia: non-detrended, raw-data chronology, detrended residual chronology, and replication. The period from 1549 (dashed line) to 2003 is replicated by $\geq 17$ tree-ring series and has the subsample signal strength (SSS) $>0.85$.

The results of heteroconnection of the southeast Slovenian oak chronology with the chronologies of other tree species in Slovenia were all statistically significant. The highest agreements $(\mathrm{t}=6.0$ and 5.8) were obtained with ash and beech, respectively, originating from the same area. The

Table 2. Descriptive statistics of the southeast Slovenian oak chronology from 1456-2003, based on 183 trees and 18,390 tree rings.

\begin{tabular}{lcc}
\hline \multicolumn{1}{c}{ Chronology type } & Raw & Residual \\
\hline Mean (mm) & 1.71 & 0.994 \\
Median (mm) & 1.67 & 1.000 \\
Mean sensitivity & 0.12 & 0.11 \\
Standard deviation (mm) & 0.40 & 0.10 \\
Autocorrelation order 1 & 0.77 & 0.001 \\
Autocorrelation order 2 & 0.25 & 0 \\
Autocorrelation order 3 & 0.17 & 0.008 \\
Mean correlation between trees & 0.12 & 0.255 \\
Signal-to-noise ratio & 6.11 & 14.05 \\
Expressed population signal & 0.86 & 0.93 \\
Variance in first eigenvector $(\%)$ & 27.7 & 29.5 \\
\hline
\end{tabular}

agreement with the Slovenian fir chronology was statistically significant as well $(\mathrm{t}=4.1)$.

\section{The Climate Signal in the Southeast Slovenian Oak Chronology}

Climate accounts for a high amount of the tree-ring width variability of oak in southeastern Slovenia $\left(r^{2}=0.51\right)$. Below-average temperature and above-average precipitation in June, i.e. a cool and moist June, proved to be the most significant factors favoring oak growth (Figure 6a). Both factors showed remarkable stability over a period of about 100 years (Figure 6b). In contrast, the positive influence of previous October and current September temperatures is not stable over time and is significant only for certain periods.

The correlation ( $\mathrm{r}$ ) between the residual treering chronology and June precipitation is 0.56 while the correlation with June temperature series is -0.55 . In order to highlight the most distinct climate signal, temperature and rainfall of June were combined into one simple variable and graphically compared with the tree-ring width 


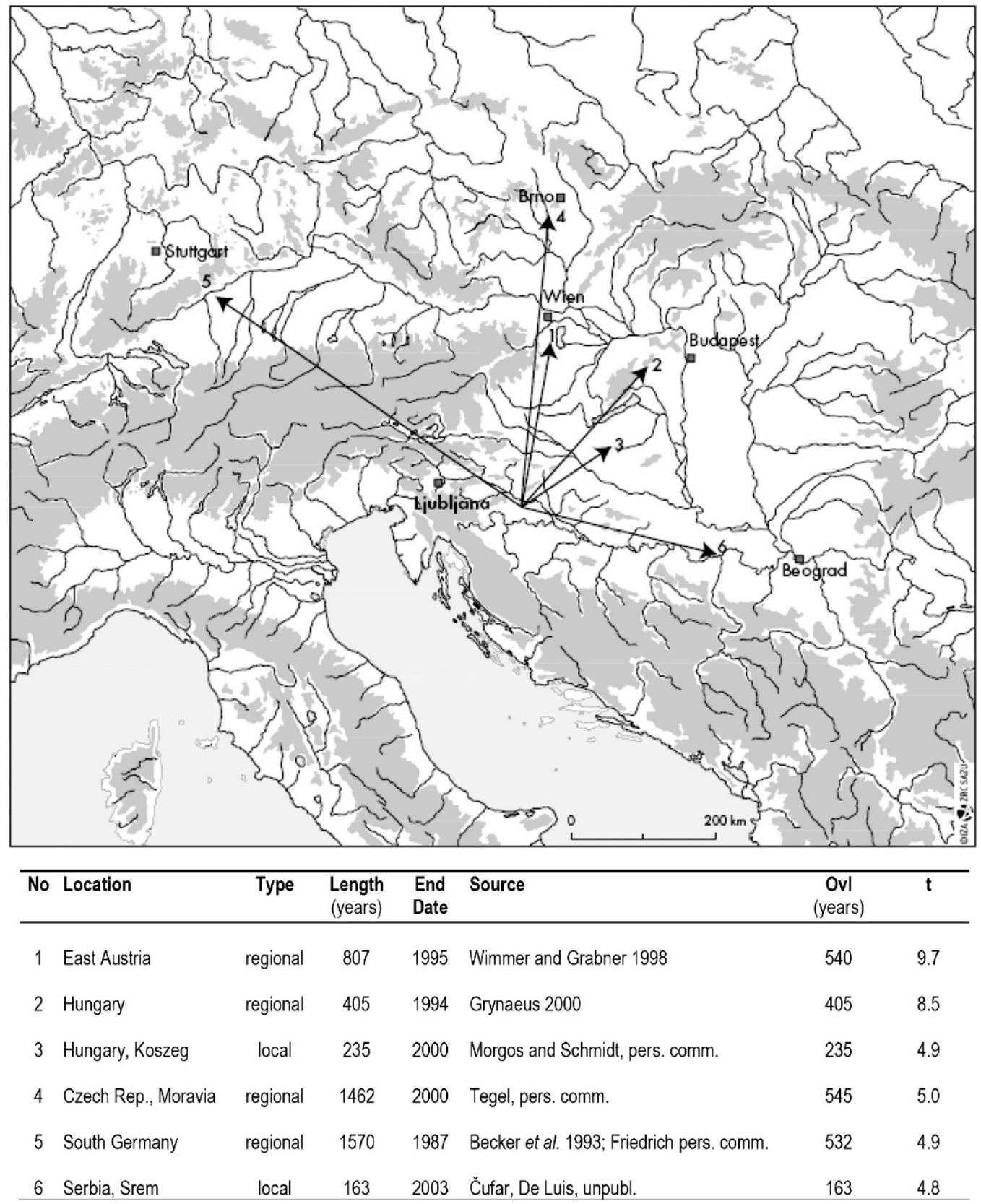

Figure 5. Teleconnection between the southeast Slovenian oak chronology (1456-2003) with other oak chronologies (arrows 1-6). Ovl - period of overlapping; $\mathrm{t}$ - $\mathrm{t}$-value.

series (Figure 7). This combination was obtained by normalizing the precipitation and temperature series and then taking the difference between them for each single year. This new variable (PP-T) correlated with the tree-ring chronology at $r=0.65$.

\section{The Castle of Pišece - An Example of Dating and Reconstructing Past Human Activities}

The castle of Pišece (Figure 8) is an important building of Slovenian cultural heritage. It is a 

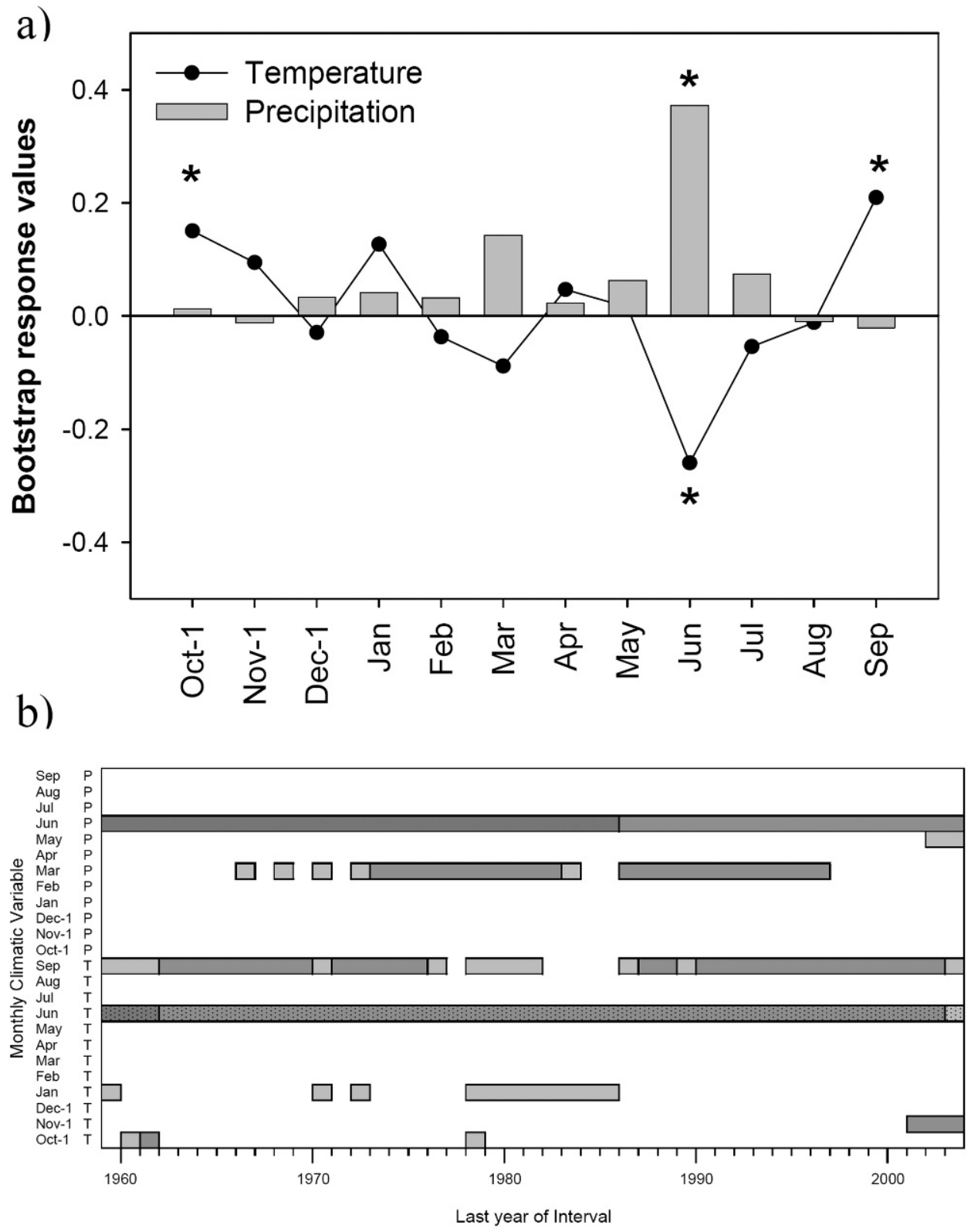

Color scale

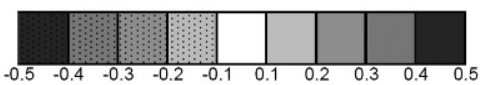

Figure 6. Southeast Slovenian oak chronology and climate: (a) response values calculated between the residual chronology and monthly temperature (lines) and precipitation (bars) from previous October to current September between 1900 and 2003 ; stars indicate significance at 95\% level; (b) moving response function (interval length of 60 years); first interval goes from 1900 to 1959 and last one from 1944 to 2003. Months with '-1' indicate months of the previous year (i.e. Dec-1). 


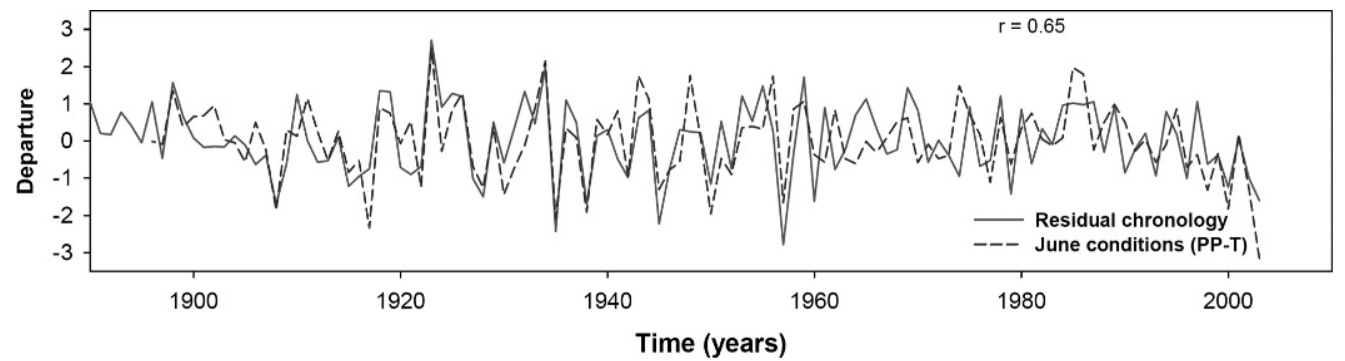

Figure 7. Comparison of the southeast Slovenian residual oak chronology and weather conditions (precipitation and temperature, PP-T) in June; both time series are normalized.

complex edifice whose history goes back to the $12^{\text {th }}$ Century. Because of its strategic location on the border between Slovenia and Croatia, it was founded as a fortress. It was later gradually modified and enlarged and finally became a residential castle. Based on written documents, as well as on the various building styles with distinct romanesque, gothic, renaissance and baroque elements (Golob, personal communication), its history could be well reconstructed and a hypothesis on the building phases could be postulated. The location of the castle within the sampling area for the southeast Slovenian oak chronology provides the opportunity for testing its quality as a dating tool.

From a total of 102 sampled construction elements, 40 were of oak and 27 of them were dendrochronologically dated. In Figure 8, their tree-ring series are arranged according to the sapwood/heartwood border, thus approximately reflecting clusters of felling dates. The timbers mainly represent two building phases. The timbers felled in the second half of the $16^{\text {th }}$ Century correspond to the renaissance phase, with several repair activities. Most interesting of this period is the painted wooden ceiling, in which painted panels made of fir and spruce are attached to an oak construction. Its discovery was a great surprise, because it had been hidden for centuries, up to the most recent restoration in 2005. The timbers felled in the second half of the $17^{\text {th }}$ Century are linked to rebuilding activities in the baroque period. An in-depth interpretation of building phases will be evaluated by architectural historians.

Because the sapwood was only partly preserved on many samples it would be helpful to know the average number of sapwood rings of Slovenian oaks in order to more precisely determine the felling years of the trees. For the time being, we assume that the number of sapwood rings is similar as for oaks in Hungary where a mean value of $17(+2 /-5)$ years is applied (Grynaeus, personal communication).

The wooden constructions, in addition to the dating of the timbers, give information on the use of wood and on its preservation to date. However, no wood was found from the $12^{\text {th }}$ and the $13^{\text {th }}$ Century phases. The wooden constructions from the $16^{\text {th }}$ and $17^{\text {th }}$ Centuries were entirely made of oak. The leading wood species in the $18^{\text {th }}$ Century was silver fir, dated to 1752 using a Slovenian silver fir chronology (Levanič and Čufar 1997), and sweet chestnut dated to 1758 by heteroconnection with the southeast Slovenian oak chronology. Oak from this period occurs only rarely.

The oaks were generally slow-growing trees (tree-ring width $0.5-1 \mathrm{~mm}$ ), which are typical for sessile oak on dry sites. Sessile oak is considered to have been the main component of natural forests in the hilly region around Pišece at the time of the foundation of the castle. The land was later deforested in favor of agriculture, particularly vineyards. Silver fir (dated to 1752) was most likely transported to Pišece from forests within a distance of $50 \mathrm{~km}$ or more. The sweet chestnut from the $18^{\text {th }}$ Century constructions is thought to have originated from the surrounding forests, where it was introduced because of its edible fruits. Its timber has often been used as a substitute for oak. Other wood species in the constructions were beech, Norway spruce, and even plane (Platanus sp.) and white pine (Pinus strobus L.), which possibly originated from the 

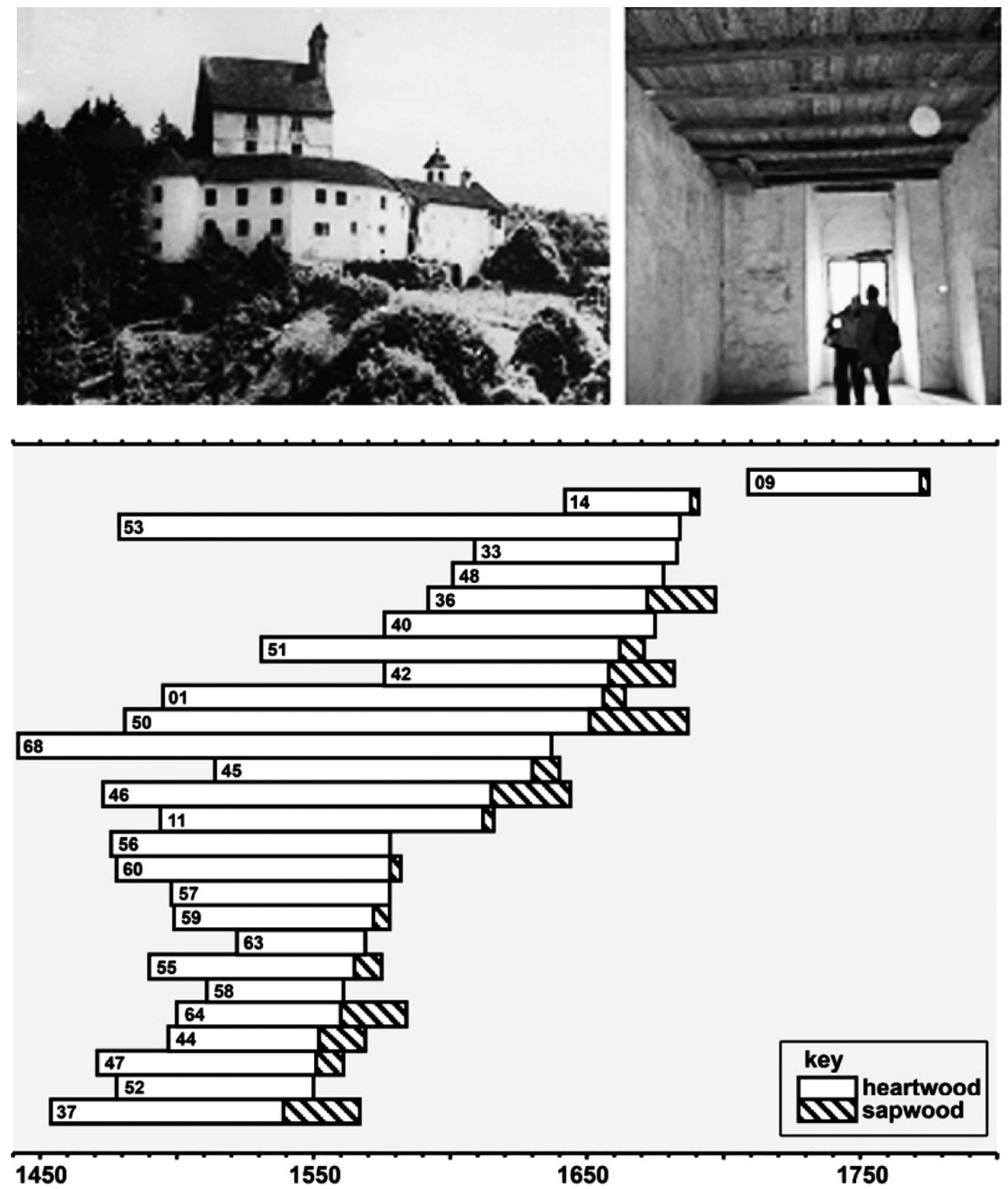

Figure 8. Castle of Pišece: view of the castle, wooden ceiling, and time spans of dated oak-tree-ring series differentiated into sapwood (hatched) and heartwood (white). Photo of the castle is from the archive of ZVKDS OE Novo mesto. 
English park of the castle established in the $19^{\text {th }}$ Century.

\section{DISCUSSION AND CONCLUSIONS}

Ten years after dendrochronology was introduced in Slovenia, a 548-year regional tree-ring chronology for oak has been assembled with treering series from living trees and historic timbers. The study area, characterized by a temperatehumid climate, was for a long time considered to be sub-optimal for dendrochronological research. However, this was also the early sentiment for many other European regions, such as Ireland (Baillie 1973), northern Germany (Eckstein et al. 1970; Eckstein 1972) or, most recently, Flanders/ Belgium (Haneca et al. 2006), where dendrochronology has meanwhile been solidly established.

The new Slovenian chronology is well-replicated and for the time being the longest one south and southeast of the Alps. It contains a clear regional signal and therefore offers the prospect of being used as 'tree-ring calendar' for dating various kinds of wooden historic objects and thus past events, including expansion beyond the limits of the study area. At the same time, this chronology will be the basis for further extensions back into the past; the timbers from the Pišece Castle, for example, already extend the chronology back to A.D. 1442. The most challenging goal in the region, however, remains the dating of the large amount of prehistoric wood, particularly from the Roman period and the period 3500-2500 $\mathrm{BC}$, when the Ljubljansko barje (Ljubljana Moor) near Ljubljana was an important site of a circumalpine pile dwelling network for which several 'floating' chronologies of oak, ash and beech have already been developed (Čufar et al. 1997; Velušček and Čufar 2002).

There is distinct evidence that early-summer rainfall and temperature are the dominant growthlimiting factors of oak in the region. The average mean June temperature of $17.7^{\circ} \mathrm{C}$ (range 14.6$22.7^{\circ} \mathrm{C}$ ) and average sum of precipitation around $134 \mathrm{~mm}$ together with the longest photoperiod, seem to provide optimal conditions for wood production. Other studies have shown that favorable May and June conditions in Slovenia also positively affect flowering and crops of several wild and cultivated plants (e.g. Črepinšek et al. 2006). Importance of longest photoperiod also proved to be crucial for growth of fir and spruce in Slovenia (Gričar 2007) and of several other tree species in the northern hemisphere (Rossi et al. 2006).

The clear regional, or even supra-regional, signal reflected by the Slovenian oak chronology has been demonstrated to be climatic in its nature. Obviously, early summer conditions also determine the growth of other tree species, such as beech, ash, and fir in the same area, giving rise to the dating of historic non-oak timbers by heteroconnection with the oak chronology. However, heteroconnection is not necessarily assured continuously and spatially, but must be empirically checked and proven for each period and locality (e.g. Müller-Stoll 1951; Groves and Hillam 1988; Billamboz 2003). Our results indicate that earlysummer weather conditions also possibly limit the growth of oak in neighboring countries, even north of the Alps up to south Germany, provided that the site conditions, such as soil, water storage capacity, are similar to our study region. Of particular interest, of course, are not the regions north of the Alps, which are already wellestablished dendrochronologically, but the neighboring regions south and southeast of Slovenia, such as Croatia, Serbia, Bosnia and Herzegovina show a paucity of tree-ring chronologies, despite their rich and priceless, ancient, wooden cultural heritage (e.g. Cufar et al. 2006). The construction of a tree-ring chronology of living oaks in Srem, Serbia, is a first step towards future networking. Networking among the tree-ring laboratories within the area south and southeast of the Alps will be necessary to meet the challenge of building a southeast European, millennium-length regional oak chronology similar to the achievements accomplished north of the Alps (e.g. Leuschner et al. 2002; Friedrich et al. 2004; Haneca et al. 2005).

The Slovenian oak chronology is also of paleoclimatic importance. Because instrumental climate records in Slovenia and in the surrounding countries are in general only several decades long, climate data derived from tree rings are expected 
in the medium-term to provide urgently needed information on paleoclimate/environment and its variability. In particular, the weather in June will be the climatic signal on which future studies will have to focus. The signal of June precipitation and temperature has proven to be strong and stable in time. At the same time, June weather conditions have certainly been decisive for past agriculturebased human societies. We therefore have reasonable expectations of a reconstruction of June rainfall/temperature, as a first step for the past 500 years, and validating such data by other evidence, such as written records on crop failures, diaries, annals and the like.

In conclusion, the objectives of the present feasibility study have been achieved and call for further research, in order to study and better comprehend the cultural and natural paleo-environment in southeast Europe.

\section{ACKNOWLEDGMENTS}

We are grateful to Tomaž Golob, Josip Korošec, Dušan Strgar and Dušan Štepec for their great support of our work on historic buildings. Thanks to Michael Friedrich, Michael Grabner, Andras Grynaeus, Andras Morgos, Burkhardt Schmidt and Willy Tegel for entrusting us with their reference chronologies for comparison, Lučka Kajfež Bogataj for her help with climatic data and Mateja Belak for preparing the maps.

The work was funded by the Ministry of Higher Education, Science and Technology of the Republic of Slovenia, Research Program "Lesarstvo", and by the Spanish Ministry of Education and Science, projects REN2003-07453 and CGL2005-04270.

\section{REFERENCES CITED}

Alexandersson, H., 1986. A homogeneity test applied to precipitation data. Journal of Climatology 6:661-675.

Baillie, M. G. L., 1973. A recently developed Irish tree-ring chronology. Tree-Ring Bulletin 33:15-22.

— 1995. A Slice through Time. B.T. Batsford Ltd., London.

Baillie, M. G. L., and J. R. Pilcher, 1973. A simple cross-dating program for tree-ring research. Tree-Ring Bulletin 33:7-14.

Baillie, M. G. L., and D. M. Brown, 2002. Oak dendrochronology: Some recent archaeological developments from an Irish perspective. Antiquity 76:497-505.
Becker, B., 1993. An 11,000-year German oak and pine dendrochronology for radiocarbon and calibration. Radiocarbon 35:201-213.

Becker, B., and B. Schmidt, 1990. Extension of the European oak chronology to 9224 years. PACT 29:37-50.

Billamboz, A., 2003. Tree rings and wetland occupation in southwest Germany between 2000 and 500 BC: Dendrochronology beyond dating in tribute to F.H. Schweingruber. Tree-Ring Research 59(1):37-49.

Biondi, F., 1997. Evolutionary and moving response functions in dendroclimatology. Dendrochronologia 15:139-150.

Biondi, F., and K. Waikul, 2004. DENDROCLIM2002: A C++ program for statistical calibration of climate signals in treering chronologies. Computers \& Geosciences 30:303-311.

edited by Cook, E. R., and L. A. Kairiukstis. Methods of Dendrochronology: Applications in the Environmental Sciences. Kluwer Academic Publishers, Dordrecht.

Cook, E. R., and K. Peters, 1997. Calculating unbiased tree-ring indices for the study of climatic and environmental change. Holocene 7(3):361-370.

Čater, M., 2003. Pedunculate oak (Quercus robur L.) crown defoliation - changes on permanent research plots. Ekologia (Bratislava) 22(4):430-443.

Čater, M., and T. Levanič, 2004. Increments and environmental conditions in two Slovenian pedunculate-oak forest complexes. Ekologia (Bratislava) 23(4):353-365.

Čater, M., and F. Batič, 2006. Groundwater and light conditions as factors in the survival of pedunculate oak (Quercus robur L.) seedlings. European Journal of Forest Research 125(4):419-426.

Črepinšek, Z., L. Kajfež-Bogataj, and K. Bergant, 2006. Modelling of weather variability effect on phytophenology. Ecological Modelling 194(1-3):256-265.

Čufar, K., T. Levanič, A. Velušček, and B. Kromer, 1997. First chronologies of the Eneolithic pile dwellings from the Ljubljana moor, Slovenia. Dendrochronologia 15:39-50.

Čufar, K., and T. Levanič T, 1999a. Tree-ring investigations in oak and ash from different sites in Slovenia. Phyton (Austria) 39:113-116.

Čufar, K., and T. Levanič, 1999b. Progress of dendrochronological research in Slovenia. Dendrochronologia 16-17: 173-181.

Čufar, K., T. Korenčič, and J. Trajković, 2006. Drvo s tri arheološka nalazišta u Hrvatskoj i mogućnosti njegova istraživanja [Wood from three archaeological sites in Croatia and its research potential]. Drvna Industrija 57(2):67-73.

Dean, J. S., 1996. Dendrochronolgy and the study of human behavior. In Tree Rings, Environment and Humanity, edited by J. S. Dean, D. J. Meko, and T. W. Swetnam, pp. 461-469. Radiocarbon, Tucson, Arizona.

Di Filippo, A., F. Biondi, K. Cufar, M. De Luis, M. Grabner, M. Maugeri, E. Presutti Saba, B. Schirone, and G. Piovesan, 2007. Bioclimatology of beech (Fagus sylvatica L.) in the Eastern Alps: Spatial and altitudinal climatic signals identified through a tree-ring network. Journal of Biogeography 34(11):1873-1892.

Eckstein, D., 1972. Tree-ring research in Europe. Tree-Ring Bulletin 32:1-18. 
Eckstein, D., J. Bauch, and W. Liese, 1970. Aufbau einer Jahrringchronologie von Eichenholz für die Datierung historischer Bauten in Norddeutschland. Holz-Zentralblatt 96:674-676.

Eckstein, D., and S. Wrobel, 1982. Dendrochronology in Europe - with special reference to northern Germany and southern Scandinavia. In Second Nordic Conference on the Application of Scientific Methods in Archaeology, edited by T. Hackens, and V. Mejdahl. PACT 7(1):11-25.

Friedrich, M., S. Remmele, B. Kromer, J. Hofmann, M. Spurk, K. F. Kaiser, C. Orcel, and M. Küppers, 2004. The 12,460year Hohenheim oak and pine tree-ring chronology from Central Europe - a unique annual record for radiocarbon calibration and paleoenvironment reconstructions. Radiocarbon 46(3):1111-1122.

Gričar, J., 2007. Xylo- and Phloemogenesis in Silver Fir (Abies alba Mill.) and Norway spruce (Picea abies (L.) Karst.). Slovenian Forestry Institute, Ljubljana.

Groves, C., and J. Hillam, 1988. The potential of non-oak species for tree-ring dating in Britain. In Science and Archaeology, edited by E. A. Slater, and J. O. Tate, pp. 567-579. British Archaeological Reports British Series 196, Glasgow.

Grynaeus, A., 1996. Progress of dendrochronological research in Hungary. Dendrochronologia 14:223-226.

- 2000. Dendrochronology and history. In Dating Undated Medieval Charters, edited by M. Gervers, pp. 213-220. Boydell Press, Woodbridge, UK.

Guiot, J., 1991. The bootstrapped response function. Tree-Ring Bulletin 51:39-41.

Haneca, K., T. Wazny, J. Van Acker, and H. Beeckman, 2005. Provenancing Baltic timber from art historical objects: Success and limitations. Journal of Archaeological Science 32(2):261-271.

Haneca, K., I. Boeren, J. Van Acker, and H. Beeckman, 2006. Dendrochronology in suboptimal conditions: Tree rings from medieval oak from Flanders (Belgium) as dating tools and archives of past. Vegetation History and Archaeobotany 15: 137-144.

Holmes, R. L., 1994. Dendrochronology Program Library User's Manual, Laboratory of Tree-Ring Research. University of Arizona, Tucson, USA.

Kelly, P. M., H. H. Leuschner, K. R. Briffa, and I. C. Harris, 2002. The climatic interpretation of pan-European signature years in oak ring-width series. Holocene 12(6):689-694.

Lavier, C., 2000. The diversity of dendrochronological investigations in France and links with other European laboratories. In Proceedings of the International Dendrochronological Symposium, Nara, Japan, edited by M. Sawada, and T. Mitsutani, pp. 13-24. Nara.

Leuschner, H. H., U. Sass-Klaassen, E. Jansma, M. G. L. Baillie, and M. Spurk, 2002. Subfossil European bog oaks:
Population dynamics and long-term growth depressions as indicators of changes in the Holocene hydro-regime and climate. Holocene 12(6):695-706.

Levanič, T., 1993. Vpliv melioracij na debelinsko rast in prirastek črne jelše, ozkolistenga jesena in doba v Prekmurju [Effects of hydromelioration on diameter growth and increment of black alder, ash and oak in Slovene Prekmurje]. Zbornik Gozdarstva in Lesarstva 42:7-65.

Levanič, T., and K. Čufar, 1997. Construction of a Slovene Dinaric silver fir (Abies alba Mill.) regional chronology. Dendrochronologia 15:183-190.

Martinelli, N., 1990. Una cronologia della quercia per l'antica eta del Bronzo dell'area benacense (Italia settentrionale). Dendrochronologia 8:141-150.

Martinelli, N., P. Nola, and O. Pignatelli, 1992. Tree-ring analysis on oak in northern Italy. In Tree Rings and Environment, Lundqua Report 34, edited by T. S. Bartholin, B. E. Berglund, D. Eckstein, F. H. Schweingruber, and O. Eggertsson, pp. 222-224. Department of Quaternary Geology, Lund University, Sweden.

Martinelli, N., O. Pignatelli, and M. Romagnoli, 1994. Primo contributo allo studio dendroclimatologico del cerro (Quercus cerris L.) in Sicilia. Dendrochronologia 12:61-76.

Müller-Stoll, H., 1951. Vergleichende Untersuchungen über die Abhängigkeit der Jahrringfolgen von Holzart, Standort und Klima. Bibliotheca Botanica 122:1-93.

Nola, P., 1991. Primo approccio alla dendroclimatologia della quercia (Quercus robur L. e Quercus petraea (Mattuschka) Liebl.) in Pianura Padana (Italia Settentrionale). Dendrochronologia 9:71-94.

Ogrin, D., 1996. Podnebni tipi v Sloveniji [The climate types in Slovenia]. Geografski vestnik 68:39-56.

Rossi, S., A. Deslauriers, T. Anfodillo, H. Morin, A. Saracino, R. Motta, and M. Borghetti, 2006. Conifers in cold environments synchronize maximum growth rate of tree-ring formation with day length. New Phytologist 170:301-310.

Schweingruber, F. H., 1988. Tree Rings: Basics and Applications of Dendrochronology. D. Reidel, Dordrecht.

Velušček, A., and K. Čufar, 2002. Dendrokronološke raziskave kolišč na Ljubljanskem barju - stanje 2001 [Dendrochronological investigation into the pile-dwelling settlements of the Ljubljana Marshes - the situation in 2001]. Arheooški Vestnik 53:59-67.

Wazny, T., and D. Eckstein, 1991. The dendrochronological signal of oak (Quercus spp.) in Poland. Dendrochronologia 9: 35-49.

Wimmer, R., and M. Grabner, 1998. Standardchronologien in Österreich als Basis für die dendrochronologische Datierung. Archäologie Österreichs 9(2):79-85.

Received 8 August 2007; accepted 23 February 2008. 